\title{
TAXONOMY, ECOLOGY, AND DISTRIBUTION OF RHYNCHOSPORA (CYP.) IN SURINAME
}

\author{
J. C. LINDEMAN and J. VAN DONSELAAR
}

Instituut voor Systematische Plantkunde, Utrecht

\section{SUMMARY}

At present 38 species of Rhynchospora, now including also Dichromena, are known from Suriname, two of which with two varieties. Two new species are described here: $R \boldsymbol{h}$. guianensis and $R h$. sublanata. A key to the Suriname species is presented.

For every taxon the distribution and, where known, a brief characteristic of its ecology in Suriname are given.

\section{INTRODUCTION}

In the present review all Rhynchospora species and infraspecific taxa found and recognized so far in Suriname are summarized. The following categories may be distinguished (the numbers refer to the list under 3):

a. Species dealt with in the Flora of Suriname (UITTIEN 1934, 1943; LindemaN \& GörTS-VAN RuN 1968) under their correct names. The only reference made to them here is the Flora of Suriname, but often with corrected author's abbreviation. Nrs. 2, 4, 6, 8a, 8b, 9, 10, 11, 12, 14, 16, 17, 18, 19, 21, 26, 30, 33a, 35, 37.

Of 9 species incorporated in the original key for Rhynchospora (1934), as they could be expected in Suriname, 5 have since been collected, nrs. 6, 11 and 30 reported in the additions $(1943,1968)$, nrs. 22 and 38 here for the first time.

b. Species reported in the Flora of Suriname under a synonym. In these cases reference is made to the publication of the present, correct name, to the original description under the basionym if the status has been changed since, and to the synonym in the Flora. To this category belong the species of Dichromena which genus we include in Rhynchospora, following KüKENTHAL (19491951). Nrs. 1, 15, 24, 25, 27, 29, 31, 33b, 34, 36.

c. Species not mentioned in the Flora of Suriname, but referred to in one or more other papers, possibly under a synonym. The description under the present, correct name is cited, besides the original description under the basionym if the status has been changed since. Nrs. 3, 4a, 4b, 7, 13, 23.

d. Species not at all reported from Suriname in the literature or only as an unnamed collection. References as under c. Nrs. 5, 22, 28, 38.

e. New species. Here the section and, if any, the subsection to which they belong according to KüKENTHAL (1949-1951) are named. Nrs. 20, 32.

For all species the following data are added:

1. Distribution in Suriname (see fig. I). As most Rhynchospora species occur 


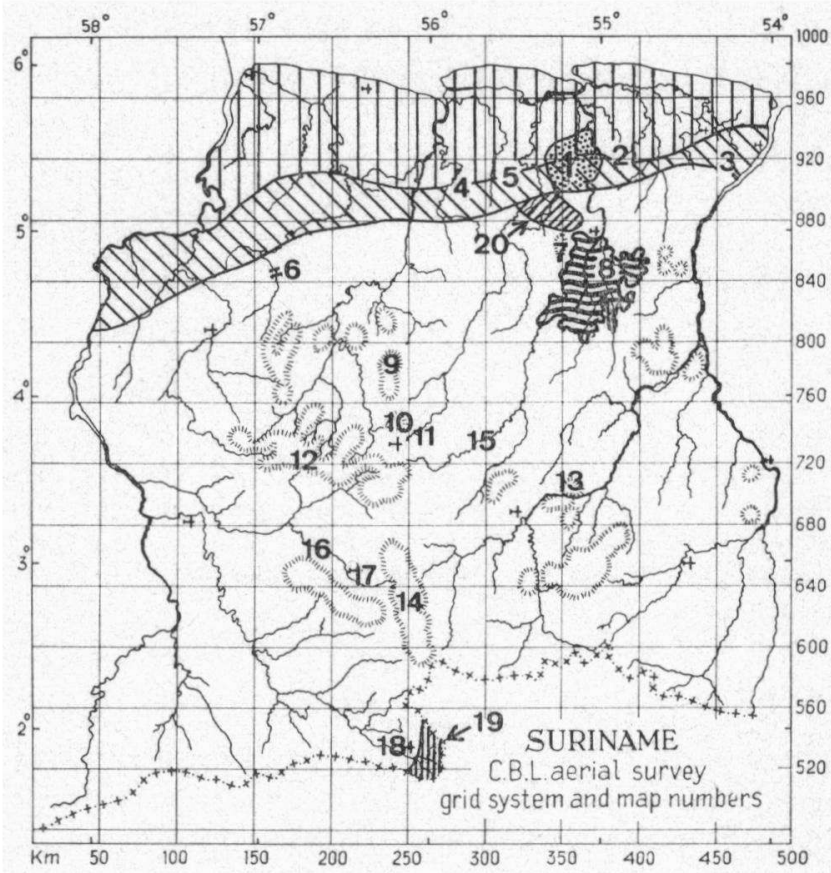

Fig. 1. Map of Suriname with main localities. 1. Zanderij, 2. Kopi, 3. Moengo tapoe, 4. Tibiti Savanna, 5. Coesewijne Savanna, 6. Blanche Marie Rapids, 7. Brownsberg, 8. Brokopondo-lake, 9. Hendriktop, 10. Tafelberg, 11. Kappel Savanna, 12. Wilhelmina Mts., 13. Mount Teboe, 14. Eilerts de Haan Mts., 15. Gran Rio, 16. Zuid River, 17. Airstrip "Kayser", 18. Airstrip "Sipaliwini", 19. Sipaliwini Savanna, 20. Area with savannas of the Sabanpasi type. Further are indicated the coastal plain and the savanna belt to the South of it, and the Para District, i.e. the area in which Zanderij (I) is situated.

in open habitat types it is useful in many instances to distinguish "the North", comprising the inhabited northernmost part of the country (the coastal plain) and the savanna belt immediately to the South of it, and "the South", with the large Sipaliwini Savanna and some other smaller savannas. Between the North and the South lies an extensive forest area. Here are remarkable the isolated, very small savannas on the flat top of the Tafelberg $(1080 \mathrm{~m})$ and the Kappel Savanna at the foot of this mountain. The Tafelberg is a remnant of the Roraima sandstone plateau that formerly covered the greater part of the Guianas, the sand of the Kappel Savanna also being derived from this sandstone. Special attention is given to these localities because of the important role the history of the Roraima plateau may have played in the geographical distribution of the tropical American flora.

2. A short ecological characteristic based on the Suriname material only. It may be not or only partially valid for the area of the species outside this country. If the syntaxonomical position of a species is stated, this refers to the 
classification of savanna vegetation-types according to the Braun-Blanquet system by van DonselaAR (1965). Only the names of the class, orders, and alliances are given, with short indications of environmental conditions:

Class Leptocoryphio-Trachypogonetea - savannas

Order Trachypogonetalia plumosi - very dry to moist soils

Alliance Cassio-Trachypogonion - white sand

Alliance Curatello-Trachypogonion - red pure and loamy sand

Alliance Rhynchosporo-Trachypogonion-sandy loam and sandy clay loam Order Paspaletalia pulchelli - wet (to very wet) soils

Alliance Syngonantho-Xyridion - white sand

Alliance Bulbostylidion lanatae - loamy sand and sandy loam

Alliance Imperato-Mesosetion - sandy loam and heavier soils

Order Panicetalia stenodis - very wet soils, watercourses and depressions

Alliance Axonopodion chrysitidis - very wet soils

Alliance Mauritio-Hypogynion - watercourses and depressions

3. General distribution, mainly after KüKENTHAL (1949-1951). For the same reasons as in the case of the Tafelberg, remnants of the former Roraima sandstone cover are mentioned separately.

\section{KEY TO THE SPECIES AND THE INFRASPECIFIC TAXA}

1. Spikelets in (1) 2 to several dense globose heads of $16-18 \mathrm{~mm}$. . . . . 2 Spikelets otherwise arranged ... . . . . . . . . . . . . 4

2. Heads in a loose corymb; bristles 6 . . . . . . . . . . . . 3 (Heads of 6-12 $\mathrm{mm}$ in a narrow, 30-50 cm long panicle; bristles absent

Guyana, Rh. exaltata Kunth)

3. Spikelets greenish brown, 6-10 mm long; nut 3-4 mm long, ellipsoid, compressed, very pale; style-base very narrow, about as long as the nut

38. $R$ h. viridi-lutea Spikelets reddish brown, 4-6 mm long, very narrow; nut $1.5 \mathrm{~mm}$ long, ovate, biconvex; style-base longer than the nut. . . . . 12. Rh. cyperoides

4. Spikelets in a single terminal head, rarely one spikelet with one bract - 5 Spikelets fascicled or solitary in panicles or corymbs. . . . . . . . 20

5. Style-branches longer than the style . . . . . . . . . . 6 Style-branches short or nearly absent . . . . . . . . . . . . . 12

6. Spikelets brown; head ovate or oblong, $2-4 \mathrm{~cm}$ long; flowers with 6 reddish brown bristles . . . . . . . 8a. Rh. cephalotes var. cephalotes Spikelets white or very pale brown; bristles absent

(Pars Dichromena) 7

7. Culms filiform, $1-12 \mathrm{~cm}$ long; spikelets $2-4 \mathrm{~mm}$ long; leaves $1-2 \mathrm{~mm}$ wide ................. . 8

Culms not filiform, at least $15 \mathrm{~cm}$ long; spikelets $5-12 \mathrm{~mm}$ long; leaves usually wider ................. 9

8. Only one spikelet, rarely exceeded by its bract; nut transversely rugose

1. $R h$. albescens 
TAXONOMY, ECOLOGY, AND DISTRIBUTION OF RHYNCHOSPORA (CYP.) IN SURINAME

Spikelets 3-6 with 3-4 foliaceous bracts; nut smooth, minutely puncticulate . . . . . . . . . . . . . 29. Rh. reptans

9. Leaves more than $5 \mathrm{~mm}$ wide, stem leaves present . . . . . . 10

Leaves at most $4 \mathrm{~mm}$ wide, all basal . . . . . . . . . . . . 11

10. Leaves ca. $15 \mathrm{~mm}$ wide, attenuate towards the base, stem leaves with a 45 $\mathrm{mm}$ long sheath; bracts 3 . . . . . . . . 24. Rh. montana Leaves 6-8 $\mathrm{mm}$ wide, stem often decumbent, rooting and proliferating at the nodes; bracts 4-5 . . . . . . . . 28. Rh. radicans var. watsonii

11. Plant with fibrous roots; sheaths not weathering; bracts green

27. Rh. pubera

Plant with an abbreviated, often curved rhizome; old sheaths weathering to fibers; bracts in the basal part shining white above

25. Rh. nervosa var. ciliata

12. (5). Bracts ovate, shorter than the spikelets . . . . . . . . . 13

Bracts foliaceous, linear, at least one equaling the spikelets, usually much longer .. . . . . . . . . . . . . . . . . 15

13. Bracts numerous, imbricate, membranous, pale brown; leaves herbaceous, flat, ciliate near the base ........ 3. Rh. armerioides

Bracts 1-4 . . . . . . . . . . . . . . . . . . . . . . 14

14. Culms and leaves filiform, usually curved; head with 2-8 linear spikelets and 1 bract ............... . 11. Rh. curvula

Culm rigid; leaves rigid, induplicate, 3-5 $\mathrm{mm}$ wide, with scabrous margins; head dense, globose, with 3-4 hard, shining brown bracts with rounded, mucronate apex . . . . . . . . . . . 18. Rh. globosa

(Leaves 1.5-2 mm wide, not rigid; head hemispheric, with 2-4 brown cuspidate bracts . . . . . . . . Guyana, Rh. subplumosa C.B. Clarke)

15. (Bracts 3 or 4 , long and leaf-like but less rigid than the leaves; head subglobose, $10-14 \mathrm{~mm}$ in diameter, bristles absent

Guyana, Rh. longibracteata Boeck.)

Bracts short, different from the leaves, the longest at most $3 \mathrm{~cm}$ long . . 16

16. Plant with creeping rhizome, culms single, rarely 2 (3) . . . . . . 17

Plant caespitose, with several culms . . . . . . . . . . . 18

17. Head with $20-40$ spikelets $3-5 \mathrm{~mm}$ long; nut biconvex

21. $R$ h. heterocaulis

Head with 5-10 (-20) spikelets 6-8 mm long; nut with flattened incurved wings, costate on the interior side (Fig. $2 a, b, c)$ 13. Rh. denticulata

18. Head conical inside the stiff suberect bracts; spikelets with 3 lower glumes ciliate; nut biconvex, not winged . . . . . . . 2. Rh. arenicola

Head hemispheric with patent bracts; spikelets glabrous; ovary winged near apex, nut concave-convex, broadly winged . . . . . . . 19

19. Culms and leaves slightly hairy, leaf-margins ciliate

4a. $R h$. barbata f. barbata

Culms and leaves (nearly) glabrous . . . . . 4b. Rh. barbata f. glabra

20. (4). Style-branches short or nearly absent; 6 bristles longer than the nut 
Style-branches as long as the style; bristles present or absent . . . . . 27

21. Culms and leaves filiform; spikelets $2-4 \mathrm{~mm}$ long; nut $1 \mathrm{~mm}$ or less long; bristles absent ................. . 22

Leaves 4 or more mm wide; spikelets 5 or more mm long . . . . . 23

22. Spikelets $2-3 \mathrm{~mm}$ long; nut less than $1 \mathrm{~mm}$ long, nearly globose with a very small roundish style-base; caespitose plant without rhizome; sheaths not weathering . . . . . . . 33b. Rh. tenella var. haplostylis

Spikelets 3-4 mm long; nut $1 \mathrm{~mm}$ long, ovate, turgidly biconvex; style-base triangular, as wide as the nut; plant caespitose with short horizontal rhizome; sheaths weathering to brown fibers . . . . 7. Rh. caracasana

23. Leaves up to $7 \mathrm{~mm}$ wide . . . . . . . . . . . . . . 24

Leaves 7-20 mm wide . . . . . . . . . . . . . . 25

24. (Spikelets ca. $6 \mathrm{~mm}$ long, in 3-4 corymbs; nut with hollow sides; leaves with scabrous margins

Guyana, Rh. amazonica Poepp. et Kunth var. guianensis Kük.) Spikelets 6-8 mm long, in lax corymbs; nut biconvex; leaves not scabrous

37. Rh. triflora

25. Spikelets 7-11 mm long, in open, $3-4 \times$ subumbellate corymbs; nut $6 \mathrm{~mm}$ long; style-base $4 \mathrm{~mm}$ long, much narrower than the nut, not sulcate (Fig. 2d, Photo 1) . . . . . . . . . . 20. Rh. guianensis Spikelets $5-8 \mathrm{~mm}$ long, fasciculate; nut $3 \mathrm{~mm}$ long or less; style-base as long and as wide as the nut, on both sides sulcate . . . . . . . 26

26. Spikelets 6-8 mm long, 2-5-fasciculate; style-base bilobed; leaves not trabeculate . . . . . . . . . . . 10. Rh. corymbosa Spikelets 5-6 mm long, 8-30-fasciculate; style-base slightly 4-lobed; leaves, especially the sheaths, trabeculate . . . . . 17. Rh. gigantea

27. Bristles present . . . . . . . . . . . . . . . . . 28

Bristles absent . . . . . . . . . . . . . . . . . 33

28. Spikelets 3-4 mm long, reddish brown, fascicled, in 1-3 contracted corymbs .. . . . . . . . . . . . . . . . . . . 29

Spikelets 5-8 mm long, in 1-4 spike-like contracted or open corymbs . 31

29. Nut transversely rugose; bracts about as long as the corymbs; leaves flat, 2-4 mm wide . . . . . . . . . . . . 31. Rh. rugosa

Nut smooth; bracts longer than the corymbs; leaves canaliculate and narrower . . . . . . . . . . . . . . . . . . . . 30

30. Nut with a narrow, smooth style-base; plant rigid

15. Rh. fascicularis var. distans

Nut with a wide, triangular, hairy, scabrous style-base; plant more or less flaccid . . . . . . . . . . . 16. Rh. flifolia

31. Spikelets $7-8 \mathrm{~mm}$ long, in open corymbs; glumes aristate; plant hairy or glabrescent . . . . . . . . . . . . . 9. Rh. comata

Spikelets 5-6 mm long, in 1 or 2 spike-like contracted corymbs; glumes mucronate ................ 32

32. One dense, spike-like corymb, up to $4 \mathrm{~cm}$ long and $2 \mathrm{~cm}$ wide; spikelets smooth; leaves up to $1 \mathrm{~cm}$ wide

8a. Rh. cephalotes var. cephalotes 
TAXONOMY, ECOLOGY, AND DISTRIBUTION OF RHYNCHOSPORA (CYP.) IN SURINAME

Spike-like corymbs elongate, loose, up to $5 \mathrm{~cm}$ long and $1.5 \mathrm{~cm}$ wide; spikelets finely puberulent; leaves usually narrower

8 b. $R$ h. cephalotes var. angustifolia

33. Plant with creeping rhizome; spikelets ovate, whitish, $6-8 \mathrm{~mm}$ long, solitary in a stiff corymb. . . . . . . . . . . . 6. Rh. candida

Plant caespitose; spikelets pale to deep red brown, shorter and narrower

34. Leaves flat or conduplicate, hairy or glabrous and then more than $2 \mathrm{~mm}$ wide and glabrous . . . . . . . . . . . . . 35

Leaves setaceous, canaliculate, up to $2 \mathrm{~mm}$ wide and glabrous . . . 38

35. Spikelets 5-7 mm long, 2-5 together on short pedicels; nut 1.5-1.8 mm long with a half as long style-base as a bilobed cap; leaves usually glabrous

Spikelets up to $5 \mathrm{~mm}$ long; nut shorter than $1.5 \mathrm{~mm}$, with a semilunate, decurrent, or short triangular style-base; leaves hairy . . . . . . . 36

36. Spikelets ovate, long-pedicelled, in 3-6 open corymbs, subtended by several times longer flat leaves; nut $1-1.5 \mathrm{~mm}$ long, transversely rugose with a depressed, decurrent style-base . . . . . . 36. Rh. trichodes

Spikelets oblong to lanceolate, in 1-3 corymbs, subtended by short setaceous leaves or bracts; nut reticulate-tuberculate . . . . . . . . . 37

37. Spikelets $4-6 \mathrm{~mm}$ long, on long pedicels, producing 1 or 2 fruits; nut 1.2-1.3 $\mathrm{mm}$ long with a depressed, truncate, decurrent style-base (Fig. 2e, Photo 2)

32. Rh. sublanata

Spikelets 3-5 mm long, mostly 2-4 together on short pedicels, producing 3 to many fruits; nut $0.6-0.7 \mathrm{~mm}$ long with a somewhat narrower and $1 / 3$ as long, triangular style-base (old spikelets with a strongly zigzag naked rachilla) . . . . . . . . . . . . . 22. Rh. hirsuta

38. Spikelets 7-12 mm long, solitary in 1-3 lax corymbs. . . . . . . 39

Spikelets not more than $5 \mathrm{~mm}$ long (in diseased specimens longer and rachilla zigzag). . . . . . . . . . . . . . . . . . . . . 40

39. Spikelets 7-9 mm long; bracts shorter than the corymbs; nut obovate, 1-1.3 $\mathrm{mm}$ long, transversely rugose with a very short broadly triangular stylebase . . . . . . . . . . . . . . . 19. Rh. graminea

Spikelets 9-12 mm long; bracts longer than the corymbs; nut obovate, 1-1.5 $\mathrm{mm}$ long, finely scrobiculate; style-base a small cone in the depressed apical area . . . . . . . . . . 26. Rh. podosperma

40. Spikelets $2-3 \mathrm{~mm}$ long, on long pedicels, few; nut $0.5 \mathrm{~mm}$ long, transversely rugose with a broadly triangular, much narrower style-base

33a. Rh. tenella var. tenella

Spikelets 3-5 mm long; nut normally $1 \mathrm{~mm}$ long . . . . . . . . . . 41

41. Spikelets in 2-4 dense hemispheric corymbs; leaves rigid, $1-2 \mathrm{~mm}$ wide; nut transversely rugose with an equally broad, short, cap-like bilobed stylebase . . . . . . . . . . . . . . 35. Rh. tenuis

Spikelets in 2-4 lax corymbs; leaves not rigid, rarely over $1 \mathrm{~mm}$ wide; nut not with a cap-like style base . . . . . . . . . . . . . 42 
42. Nut truncate but not depressed and rimmed at the apex; style-base 1/3-1/4 as long, conical, with a widened base; rachilla of spikelets straight

23. Rh. junciformis

Nut with a depressed rimmed apical area with in the middle the small conical style-base; rachilla of spikelets bent . . . . . . . . . . 43

43. Nut smooth, pale yellowish with a black mark on each side and a narrow stipe, apex rimmed but hardly depressed . . . . 5. Rh. brevirostris

Nut transversely rugose, brown, apex strongly depressed . . . . . 44

44. Nut widest in the middle, the rim protruding into 2 horns as high as the style-base . . . . . . . . . . 34. Rh. tenerrima

Nut widest at the undulate $\operatorname{rim}$. . . . . . . 14. Rh. fallax

\section{LIST OF SPECIES}

1. Rh. albescens (Miq.) Kük. in Bot. Jahrb. 75:304.1951.

Isolepis albescens Miq. in Linnaea 19:226.1847. In Fl. Sur. 1,1:95.1934, as Dichromena monostachya Clarke.

Known only from two old collections in the North: border of Coropina River (Focke 1074) and a second, unknown locality in the Para District (Wullschlaegel 638).

Northern Brazil, Suriname.

2. Rh. arenicola Uitt.

In Fl. Sur. 1,1:101.1934.

In the North on savannas between Zanderij and Kopi, on wet to very wet pure white sand; scarce; characteristic species of the alliance Syngonantho-Xyridiọn (van Donselaar 1965, 1969; van DonselaAR-TEN BokKel HuININK 1966; HeYLIGERS 1963).

Outside Suriname only known from sandstone table-mountains of the Guayana highlands: Kaieteur Plateau (Guyana), Auyan-tepui, Ptari-tepuí, and Cerro Yaví (Venezuela).

3. Rh. armerioides Presl, Reliq. Haenk. $1: 197.1830$.

In the South: Sipaliwini Savanna, on very wet, slightly coloured sand, in vegetations belonging to the alliance Axonopodion chrysitidis (van Donselaar 3632) (VAN DonselaAR 1968, 1969), and on a thin layer of sandy soil overlying outcropping rock (Oldenburger \& Norde 392).

Central America, tropical South America.

4. Rh. barbata (Vahl) Kunth

In Fl. Sur. $1,1: 100.1934$.

4a. Rh. barbata (Vahl) Kunth f. barbata

Throughout the country. Savannas on soil types ranging from pure, coloured sand to heavy soil, and from dry to very wet, also in periodically dry water- 
TAXONOMY, ECOLOGY, AND DISTRIBUTION OF RHYNCHOSPORA (CYP.) IN SURINAME

courses. Characteristic taxon of the class Leptocoryphio-Trachypogonetea (Van DonselaAr 1965, 1969; van DonselaAR-TEn BoKkel HuininK 1966; TEUNISSEN \& WILDSCHUT 1970). Locally on granitic outcrops in small pockets of soil (VAN DONSELAAR \& SCHULz, in prep.).

Central America, northern and eastern South America, West Indies.

4b. Rh. barbata (Vahl) Kunth f. glabra (Maury) Kük. in Bot. Jahrb. 74:487. 1949.

Rh. barhata (Vahl) Kunth var. glabra Maury in J. de Bot. 3: 209. 1889.

In the North on savannas on pure, white, wet sand, as a characteristic taxon of the alliance Syngonant ho-Xyridion (VAN DONSELAAR 1965, 1969; HeYLIGERS 1963, not mentioning the name of the forma). In the South one collection from a small pocket in a granite flat, Sipaliwini Savanna (Oldenburger \& Norde 108). On savanna on the Tafelberg and on the Kappel Savanna, in the latter case together with specimens intermediate between this form and the typical one (SVENSON 1948; KRAMER \& VAN DONSELAAR 1968).

Northern South America, incl. the Kaieteur Plateau (Guyana).

5. Rh. brevirostris Griseb., Cat. Pl. Cub. : 246. 1886.

In the South: Sipaliwini Savanna, on wet to very wet soil (Van Donselaar 3604, 3618: VAN DonSElAAR 1969 tables 8 and 9; Oldenburger \& Norde 86).

Brazil, Suriname, Central America, West Indies.

6. Rh. candida Boeck. in Linnaea $37: 605.1873$.

In Fl. Sur. 1,1: 99. 1934, in key only; 1,2:311. 1968.

One collection from the North: loamy part of the Tibiti Savanna (Lanjouw \& Lindeman 1695); one collection from the South: Sipaliwini Savanna, near forest border, soil with hogwallow structure (Oldenburger \& Norde 671).

Northern Brazil, the Guianas, tropical Africa.

7. Rh. caracasana (Kunth) Boeck. in Linnaea 37:607. 1873.

Dichromena caracasana Kunth, Enum. Pl. 2: 281.1837.

In the North on the Sabanpasi Savanna, in open vegetation on pebble ridges as a characteristic species of the association Bulbostylidetum coniferae minoris (alliance Bulbostylidion lanatae) (LBB-Teunissen \& Wildschut 11783, 12181) (TeunisSEN \& Wildschut 1970). In the South just beyond the Brazilian frontier on savanna (Schmidt 153).

Northern and eastern South America.

8a. Rh. cephalotes (L.) Vahl var. cephalotes

In Fl. Sur. 1,1 : 106. 1934.

Throughout the country. In open vegetations, slightly shaded, on sandy loam and heavier soil types, wet to very wet, also in periodically dry watercourses; in the South also drier. Savanna scrub and bushes on loamy sand and sandy loam, dry to wet. Light wood and forest types. Less common along riverbanks, road- 
sides, in fissures in granitic outcrops, and between rocks in rapids (VAN DONSELAAR 1965, 1969; TEUNISSEN \& WILDSCHUT 1970).

Tropical America.

8b. Rh. cephalotes (L.) Vahl var. angustifolia Uitt.

In Fl. Sur. 1,1: 107. 1934.

Tafelberg: among rocks in Grace Falls (Maguire 24493), on sandstone in scrub (Geijskes 989, Maguire 24550); Wilhelmina Mountains (BW 7111); near Upper Gran Rio (Hulk 346).

Suriname only.

9. Rh. comata (Link) Schult.

In Fl. Sur. 1,1: 106. 1934.

In the mountainous interior on granite flats, in mountain forest on stony soil and apparently rare between boulders on riverbanks.

Guyana, Suriname, Amazonas, north-eastern Brazil Southward to Rio de Janeiro.

10. Rh. corymbosa (L.) Britton

In Fl. Sur. 1,1: 103. 1934.

In the North the characteristic dominant in old oligotrophic swamps with a thick peat layer and occasional in the older Cyperus giganteus-Typha-Scleria swamps near the border between young and old coastal plain (LINDEMAN 1953). In the South in swamp along creek on the Sipaliwini Savanna.

Pantropical and subtropical swamp species.

11. Rh. curvula Griseb.

In Fl. Sur. 1,1: 98. 1934, in key only; 497. 1943.

Throughout the country. Savannas, on pure, white or coloured sand to sandy clay loam, in communities belonging to the order Paspaletalia pulchelli. Optimum on wet loamy sand, in association $R$ hynchosporetum curvulae (alliance Bulbostylidion lanatae) (VAN DonselaAR 1965, 1969; van DonSElAAR-TEN BoKkel Huinink 1966; Teunissen \& Wildschut 1970). Also on Kappel Savanna (KRAMER \& VAN DONSELAAR 1968).

Central America, West Indies, northern South America, incl. the Kaieteur Plateau (Guyana).

12. Rh. cyperoides (Sw.) Mart.

In Fl. Sur. 1,1: 102. 1934.

Throughout the country. In places flooded by fresh water in the wet seasons, and staying moist or briefly drying up in the dry seasons. On all types of soil, also peat. In relatively shallow swamps of the Lagenocarpus guianensis-other Cyperaceae type of the coastal area (LINDEMAN 1953); in Eleocharis swamps and swamp savannas more inland, e.g. in the Para District; in watercourses and depres- 
TAXONOMY, ECOLOGY, AND DISTRIBUTION OF RHYNCHOSPORA (CYP.) IN SURINAME

sions in savannas (alliance Mauritio-Hypogynion) (VAN DonSELAAR 1965; LINDEMAN 1953).

Tropical America, subtropical South America, Africa.

\section{Rh. denticulata Huber in Bol. Mus. Paraense 5: 317. 1909.}

This species of which Van Donselaar had made 2 collections was recognized several years ago as distinct from all species accepted by Kükenthal in his monograph and all species published since, and this situation still stands. The species was named after its conspicuous exposed rhizome $R h$. rhizomatosa Lindeman, but not yet published; under this unpublished name, however, its place in the vegetation was discussed in van DonselaAR $(1965,1969)$ and Teunissen \& WILDSCHUT (1970).

While preparing its publication and checking its affinities to other species in the genus, it turned out that with the collection cited in the additions in Fl. Sur. 1,2: 311 . 1968 as J. P. Schulz 11039 under Rh. trichochaeta C. B. Clarke a double error had been made. This number from the LBB series was actually collected by Maas and Tawjoeran and differs from true $R \boldsymbol{h}$. trichochaeta in the presence of a rhizome and the shape of the fruit, as drawn by Clarke and observed in Ule 8083, but agrees completely with $R h$. rhizomatosa. Whereas Van Donselaar's specimens were growing separately, each with one culm, the field note by Maas states that the plant formed tufts. Apparently the rhizomes were easily separable as the mounted specimens are identical with those collected by Van Donselaar. This phenomenon proved to be the clue as the detailed description by Huber of $R h$. denticulata explicitly mentions this. Kükenthal, however, referred this species "ex descriptione" to the synonymy of $R h$. trichochaeta, in our opinion unjustifiedly. The description of $R h$. denticulata fits exactly our specimens of $R h$. rhizomatosa, which name therefore has to remain a nomen nudum. The only difference is the colour of the old sheaths, wine-red in Ducke's type collection, brown in the Suriname material. See fig. 2a. b. c.

The species is common in a limited area in the North, on a number of geologi cally and ecologically related savannas (Sabanpasi savanna-type) occurring on wet sandy loam and loamy sand, as a characteristic species of the alliance Bulbostylidion lan atae (Van Donselaar 678, 2746, 2781; LBB-Teunissen \& Wildschut 11334).Less common on the Coesewijne Savanna, $50 \mathrm{~km}$ to the North-West, on dry soil of sandy loam or sandy clay loam in the association DiperacanthoByrsonimetum verbascifoliae (alliance Rhynchospora-Trachypogonion) (Van Donselaar 537). See van DonselaAR $(1965,1969)$ and Teunissen \& WiLDSChut (1970). Another collection $150 \mathrm{~km}$ to the West, Nickerie District, in scrub savanna on pale brown loamy sand with ironstone pebbles (LBB-Maas \& Tawjoeran 11039).

Savannas of the Upper Ariramba River (Est. Pará, Brazil), Suriname.

Fig. 2. Rhynchospora denticulata: $a$ and b (Van Donselaar 678), c (LBB-Maas 11039); Rhynchospora guianensis: d (type specimen: Oldenburger \& Norde 133); Rhynchospora sublanata: e (type specimen: Oldenburger \& Norde 952). Drawings by H. R. Rypkema. 


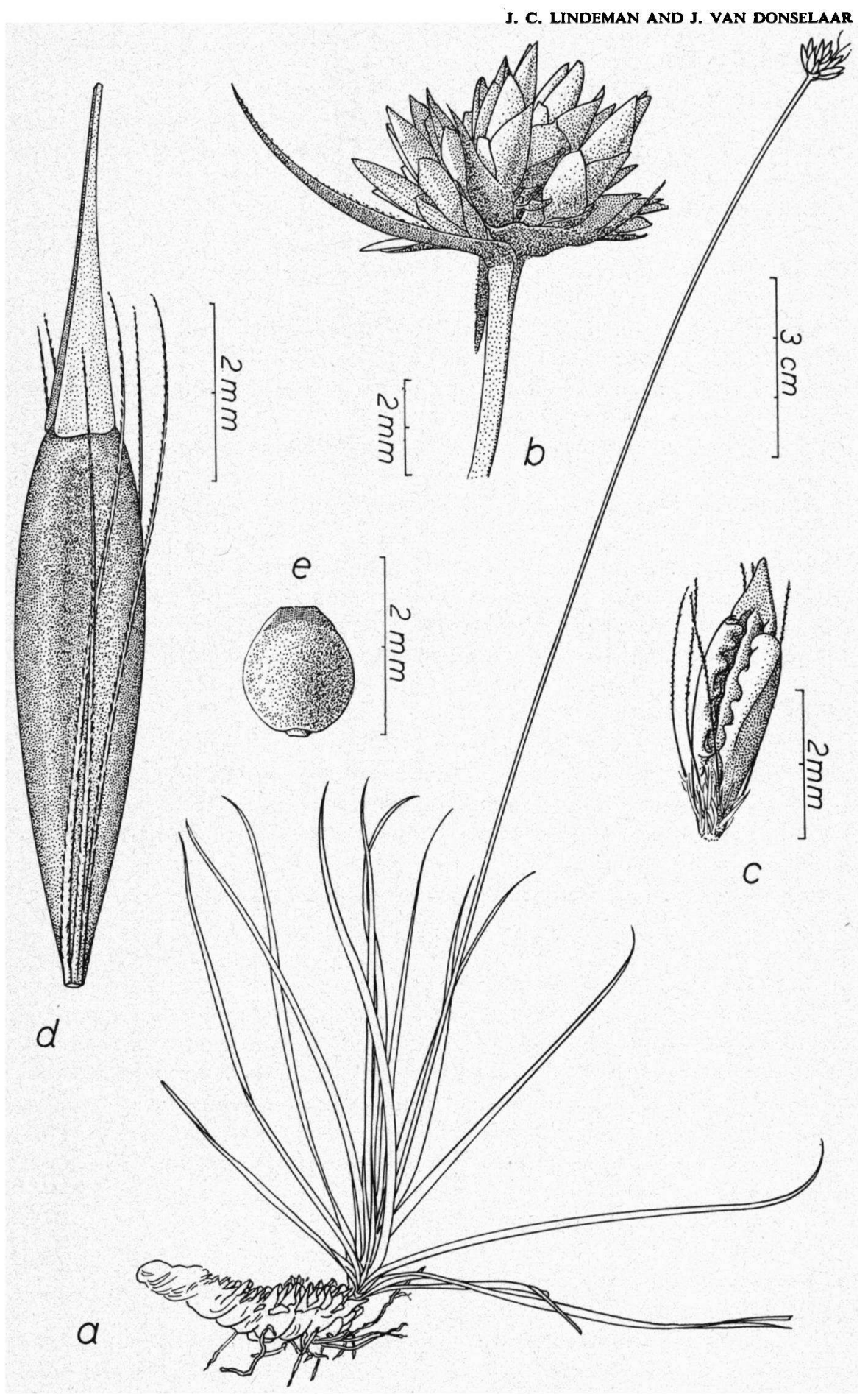


TAXONOMY, ECOLOGY, AND DISTRIBUTION OF RHYNCHOSPORA (CYP.) IN SURINAME

14. Rh. fallax Uitt.

In FI. Sur. 1,1: 105.1934.

In the interior, also in the South, on granitic outcrops, rooting in small quantities of very humic or peaty sand on rock or in crevices, not shaded (vaN DONSElaAR \& Schulz, in prep.).

Suriname only.

15. Rh. fascicularis (Michx.) Vahl var. distans (Michx.) Chapm., Fl. South. U.S.: 527. 1860.

Schoenus distans Michx., Fl. Bor. Amer. 1: 36. 1803. In Fl. Sur. 1,1: 107. 1934, and 498. 1943, as Rhynchospora distans Vahl.

In the North on savannas between Zanderij and Kopi, on pure, white, wet sand; scarce (VAN DoNSELAAR 1965).

Central America, subtropical North America, West Indies, Suriname.

16. Rh. filifolia Gray in Torrey, in Ann. Lyc. N.York. 3: 366. 1836.

In Fl. Sur. 1,2: 311. 1968.

Once collected in the North in rather open vegetation on floating peat in swamp $18 \mathrm{~km} \mathrm{~N}$ of Moengo tapoe (Lanjouw \& Lindeman 953a, 1002), but then still dubious and therefore not reported by LINDEMAN (1953).

A remarkable range extension from Atlantic North America and Cuba.

\section{Rh. gigantea Link}

In Fl. Sur. 1,1 : 103, 1934.

In the North in deep swamps in the old coastal plain in the Lagenocarpus guianensis-other Cyperaceae vegetation of floating peat (LINDEMAN 1953), later also found in swamps near Rijsdijkweg and Powaka Creek (Para District), forming dense, almost pure stands.

Cuba, Porto Rico, Guyana, Suriname, Brazil, and Paraguay.

18. Rh. globosa (H.B.K.) R. et S.

In Fl. Sur. 1,1:102. 1934.

Throughout the country. Savannas on loamy sand and heavier soil types, wet to very wet, also in periodically dry watercourses. Characteristic species of the class Leptocoryphio-Trachypogonetea; in the North optimum on heavy soil in zone along savanna watercourses, in association $\mathrm{Rhynchosporetum}$ globosae (alliance Axonopodion chrysitidis). (VAN DonselaAR 1965, 1969; VAN DONSElaAR-TEN BOKKel HuININK 1966; TEUNISSEN \& WILDSCHUT 1970).

Tropical America, subtropical South America.

\section{Rh. graminea Uitt.}

In Fl. Sur. 1,1:105. 1934.

Throughout the country. Savannas on pure, white or coloured sand and loamy sand, wet to very wet. In the North characteristic species of the order 
Paspaletalia pulchelli (alliances Syngonantho-Xyridion and Bulbostylidion lanatae); also on the Kappel Savanna; in the South on the Sipaliwini Savanna also in communities of the alliance Axonopodion chrysitidis on sandy soil (VAN DonselaAR 1965, 1969; VAN DONSELAAR-TEN BOKKEL Huinink 1966; HeYligers 1963; KRAMER \& VAN DonselaAR 1968; Teunissen \& WiLdSCHUT 1970).

Northern South America, incl. the Kaieteur Plateau (Guyana).

20. Rhynchospora guianensis Lindeman et Van Donselaar spec. nov.

Herba perennis. Culmus erectus, simplex, triangularis, marginibus paulo scabris. Folia rosulata ca. 5, supra glabra, infra costa marginibusque scabra, vaginis paulo carinatis, amplectentibus, marginibus membranaceis, apice rotundatis; folia caulina dua, inserta ad ca. $1 / 3$ et $2 / 3$ caulis, vagina clausa. Corymbus compositus, subumbellatus, terminalis, amplus, bracteis foliaceis; corymbi secundarii 3-4, approximati, ter vel quater subumbellate ramosi, multo inaequales, ramis scaberrimis. Fasciculi terminales compositi ex spiculis 7-12, illium 4-9 praesentes. Spiculae 7-11 $\times 1-2 \mathrm{~mm}$. Squamae 5, acutae, apice acute mucronatae, ochraceae, lineolis rubescentibus; tres vacuae; quarta hermaphrodita, setis 6 nuce longioribus antrorsum scabris, filamentis 3 squama brevioribus setis longioribus, pistillo; quinta masculina, staminibus 3 per squamam quartam inclusa. Stylus simplex, perlongus, basi viridi longe triangulari $4 \times 2 / 3 \mathrm{~mm}$, limbo bilobo a nuce discreta. Nux $6 \times 1 \frac{1}{2} \mathrm{~mm}$, oblonga, basi attenuata, lateribus excavata, punctulata, fusca.

Typus: Suriname, Sipaliwini Savanna, 18-IX-1968, Oldenburger \& Norde 133 [holotype U, isotypes BBS, NY].

Paratypi: Guyane française, Pariacabo, 10-VII-1914, Benoist 1406 [P]; Guyane française, savannas near Kourou, 22-VII-1962, ORSTOM-Hoock s.n. [P, U].

Perennial herb, 1.20-2 $\mathrm{m}$ high. Culm erect, simple, triangular, with slightly scabrous margins, $90-160 \mathrm{~cm}$ long and at the base up to $7 \mathrm{~mm}$ thick. Rosette leaves about $5,70-120 \times 0.7-1.5 \mathrm{~cm}$, sheaths slightly keeled, amplexicaul, the membranous margins rounded at the top. Stem leaves 2 , inserted at about $1 / 3$ and $2 / 3$ from the base, blades $50-80 \times 0.6-1.2 \mathrm{~cm}$, the closed sheaths $7-11 \mathrm{~cm}$ long. Terminal corymb subumbellate, $25-45 \mathrm{~cm}$ long, spreading, with leaf-like bracts, $7-30 \times 0.6-1 \mathrm{~cm}$. Secondary corymbs $3-4$, aggregate, $3-4 \times$ subumbellately branched, with very unequal, very scabrous branches. Sometimes in the axil of the highest stem-leaf a corymb on a long peduncle. Terminal fascicles consisting of 7-12 spikelets of which 4-9 present, the rest shed. Spikelets 7-11 $\times$ 1-2 mm. Glumes 5, acute, with a sharply mucronate tip, yellowish brown with short reddish lines, the 3 lowest empty, the fourth bisexual, with 6 retrorsely scabrous bristles exceeding the nut, 3 stamens with filaments shorter than the glumes but longer than the bristles, and a pistil; the fifth staminate, with 3 stamens, included in the fourth glume. A very long simple style, with a green long-triangular base of $4 \times 2 / 3 \mathrm{~mm}$ attached to the nut with a bi-lobed limb. Nut $6 \times 1 \frac{1}{2} \mathrm{~mm}$, with narrowed base and hollow sides, punctulate, brown. See fig. $2 d$, photo 1 . 
TAXONOMY, ECOLOGY, AND DISTRIBUTION OF RHYNCHOSPORA (CYP.) IN SURINAME

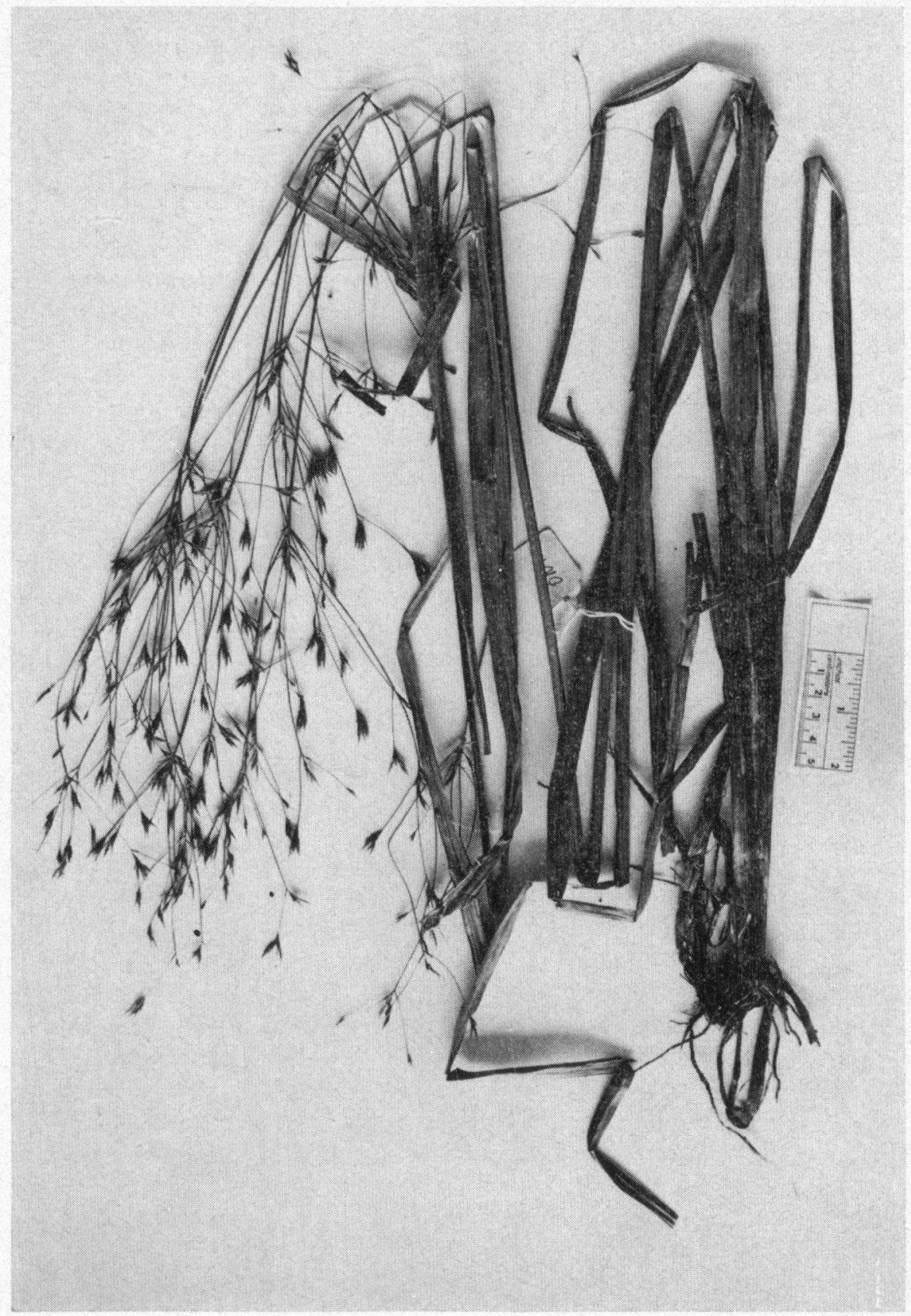

Photo 1. Rhynchospora guianensis (type specimen: Oldenburger \& Norde 133). Photo by A. Kuiper. 
The species belongs to the section Longirostres and is very closely related to $R h$. schmidtii Kük. from the West Indian islands. It differs by being much larger, having much more ample inflorescences and a less scabrous culm; the base of the style is not so long that it exceeds the glume.

The single Suriname specimen was collected in the South, on the Sipaliwini Savanna, in a wet valley under a Mauritia flexuosa palm. About the habitat of the specimens from French Guiana no more details can be given.

The species is not known from any other locality than the three listed above.

21. Rh. heterocaulis C.B. Clarke

In Fl. Sur. 1,1 : 100. 1934.

Only one old collection: S.l. (Berthoud-Coulon 52 [BM]).

Brazil, Suriname.

22. Rh. hirsuta Vahl, Enum. 2:231. 1806.

In Fl. Sur. $1,1: 99.1934$, in key only.

In the South: Sipaliwini Savanna and a savanna SW of the airstrip "Sipaliwini" (Van Donselaar 3676 and 3708, respectively), in both cases on wet to very wet soil; not uncommon.

Northern South America, Central America, West Indies.

23. Rh. junciformis (Kunth) Boeck. in Linnaea 37: 557. 1873, var. junciformis Dichromena junciformis Kunth, Enum. Pl. 2: 279. 1837.

In the South on a savanna SW of the airstrip "Sipaliwini", on slightly coloured sandy soil, very wet, in very thin and low vegetation (Van Donselaar 3668; VAN DONSELAAR 1969).

Northern South America. The Suriname station is the northernmost so far known (VAN DoNSElaAR 1968).

24. Rh. montana (Uitt.) H. Pfeiffer in Fedde Rep. 38:91. 1935.

In Fl. Sur. 1,1:97. 1934, as Dichromena montana Uitt.

Only known from the type locality: the top of Brownsberg, an isolated, 514 $\mathrm{m}$ high mountain in the centre (BW 6728).

25. Rh. nervosa (Vahl) Boeck. var. ciliata (Vahl) Kük. in Bot. Jahrb. 75: 295. 1951.

In Fl. Sur. 1,1:97. 1934, as Dichromena ciliata Vahl.

Throughout the country. In herbaceous vegetations of natural as well as secondary habitats, mainly on savannas. On many soil types but not on pure sand. In the North optimal on dry loamy sand to sandy clay loam as a characteristic taxon of the order Trachypogonetalia plumosi (alliances CuratelloTrachypogonion and Rhynchosporo-Trachypogonion) (VAN DONSESELAAR 1965, 1969; VAN DoNSELAAR-TEN BoKKEL HUININK 1966).

Tropical America, subtropical South America. 
TAXONOMY, ECOLOGY, AND DISTRIBUTION OF RHYNCHOSPORA (CYP.) IN SURINAME

26. Rh. podosperma C. Wright

In Fl. Sur. 1,2: 311.1968.

On savannas. In the North on loamy sand and heavier soil types, wet to very wet, as a characteristic species of the order Paspaletalia pulchelli (alliances Bulbostylidion lanatae and Imperato-Mesosetion), with optimum in association $\mathrm{Rhynchosporetum} \mathrm{podospermae} \mathrm{(alliance} \mathrm{Bulbostylidion}$ lanatae) (VAN DonselaAR 1965). In the South on a savanna SW of the airstrip "Sipaliwini" in communities of the alliance Bulbostylidion lanatae (VAN DONSELAAR 1969) and on the Sipaliwini Savanna.

Northern and eastern South America, West Indies.

27. Rh. pubera (Vahl) Boeck. in Linnaea 37: 528. 1871-1873.

In Fl. Sur. 1,1 : 96. 1934, as Dichromena pubera Vahl.

In sunny places subject to quick alternation of drought and moisture. Eilerts de Haan Mountains: fissure in granitic outcrops filled with sandy peat (LBBSchulz 10411); Upper Coppename River: on rock (Boon 1152); along rivers and creeks in the interior, also in the South. In the North one collection from savanna (near Zanderij II, Maguire 23644). Besides in grasslands and as a weed in other secondary habitats; common.

Northern South America, Central America, West Indies.

28. Rh. radicans (Schl. et Cham.) H. Pfeiffer var. watsonii (Britton) Kük. in Bot. Jahrb. 75: 311. 1951.

Dichromena watsonii Britton in Bull. Torr. Bot. Club 15: 101. 1888.

One collection from the interior : in high dryland forest at Jandé Creek NE of Kabelstation (Lindeman 4439), now forming part of the artificial Brokopondolake.

British Honduras, Ecuador, Guyana, Suriname, West Indies.

29. Rh. reptans (L. C. Rich.) Kük. in Bot. Jahrb. 75: 304. 1951.

Scirpus reptans L. C. Rich. in Act. Soc. Hist. Nat. Paris 1: 106. 1792.

In Fl. Sur. 1,1: 96. 1934, as Dichromena repens Vahl.

In the interior, in and along swiftly running water, temporarily submerged, on sand as well as on rock.

Northern Brazil, the Guianas.

30. Rh. rufa (Nees) Boeck.

In Fl. Sur. 1,1:99. 1934, in key only; 498.1943.

Five collections from rather different localities. In the North: Francina Savanna (= Welgelegen Savanna, Para District), on heavy, wet soil (LP-Dirven 314, 319); in the centre: Hendriktop (1080) m, on rock (Jonker \& Daniëls 998); in the South: Sipaliwini Savanna, on heavy, wet soil (Rombouts 395 A, Oldenberger \& Norde 23).

Tropical America. 
31. Rh. rugosa (Vahl) Gale in Rhodora 46:275. 1944.

Schoenus rugosus Vahl in Ecl. 2: 5. 1795. In Fl. Sur. 1,1: 106. 1934, as Rhynchospora glauca Vahl.

Throughout the country. Savannas on sandy loam and heavier soil types, very wet, also in periodically dry watercourses. Characteristic species of the order Panicetalia stenodis (VAN DonselaAR 1965, 1969).

Tropical and subtropical South America, West Indies.

\section{Rhynchospora sublanata Lindeman et Van Donselaar spec. nov.}

Herba perennis. Culmi erecti, pauci, aggregati, subtrigoni, piloselli, basi foliis rosulatis multis. Folia rosulata $1 / 4-1 / 3$ culmi aequantia, conduplicata, apice plano-triquetra, subtus lanata, supra apicem versus sublanata; folia caulina 3-5, erecta, brevia, vaginis clausis. Corymbus terminalis subpatens, bis ramosus, bracteis brevibus filiformibus. Spiculae solitariae, 4-6 $\times 1 \mathrm{~mm}$, acutae. Squamae rufae, membranaceae, margine albo-hyalino; tres vacuae; ovatae, obtusae, ciliato-aristulatae; fertiles ovato-lanceolatae, subacutae, mucronatae; una vel duae hermaphroditae, paucae imperfectae iis inclusae. Setae nullae. Stamina tria, antheris ca. $2 \mathrm{~mm}$ longis. Stylus $1 / 2-3 / 4 \mathrm{~mm}$, stigmatibus duobus ad $5 \mathrm{~mm}$; basis styli $0.2 \mathrm{~mm}$ alta, truncata, lateribus ad partem tertiam nucis decurrentibus. Nux fere orbiculata, 1.2-1.3 mm longa, forte biconvexa, straminea, reticulato-tuberculata, abrupte contracta in stipitem brevem crassum.

Typus: Suriname, savanna $2 \mathrm{~km} \mathrm{SW}$ of airstrip "Sipaliwini", 20-1-1969, Oldenburger \& Norde 952 [holotype U, isotype BBS].

Paratypi : Suriname, savanna near airstrip "Kayser” (Zuid River), 13-VIII-1963, LBB-Schulz 10436 [BBS, U]; Suriname, Sabanpasi Savanna, 16-I-1968, LBBTeunissen \& Wildschut 12185 [BBS, NY, K, U].

Perennial herb, 45-110 cm high. Culms erect, subtriangular and short-hairy, $40-100 \mathrm{~cm}$ long and $1-1.5 \mathrm{~mm}$ thick, few together, each at the base surrounded by numerous rosette leaves. Rosette leaves $1 / 4-1 / 3 \times$ the length of the culm and 2-5 mm wide, folded, with a flat triangular top, woolly on the back, somewhat woolly on the upper side towards the top. Stem leaves $3-5$, erect and short, with $3-4.5 \mathrm{~cm}$ long closed sheaths. Terminal corymbs $5-12 \mathrm{~cm}$ long and more or less spreading, twice branched, with short, filiform, ciliate bracts; the branches filiform and virtually glabrous. Sometimes a lateral corymb in the axil of the uppermost stem leaf. Spikelets solitary, 4-6 mm long and about $1 \mathrm{~mm}$ wide, acute. Glumes rufous, membranous, with white hyalinous margins; the lower three empty, ovate, obtuse, ciliate-aristulate; the fertile ones ovate to lanceolate, slightly acute and mucronate; one or two bisexual which enclose a few imperfect ones. Bristles absent. Stamens 3, with about $2 \mathrm{~mm}$ long anthers. Style 1/2-3/4 $\mathrm{mm}$, with 2 up to $5 \mathrm{~mm}$ long stigmas. Base of the style $0.2 \mathrm{~mm}$ high, truncate, with sides covering one third of the nut. Nut nearly orbicular, $1.2-1.3 \mathrm{~mm}$ long, strongly biconvex, reticulate-tuberculate, yellow, abruptly contracted into a short, thick stipe. See fig. $2 e$, photo 2. 
TAXONOMY, ECOLOGY, AND DISTRIBUTION OF RHYNCHOSPORA (CYP.) IN SURINAME

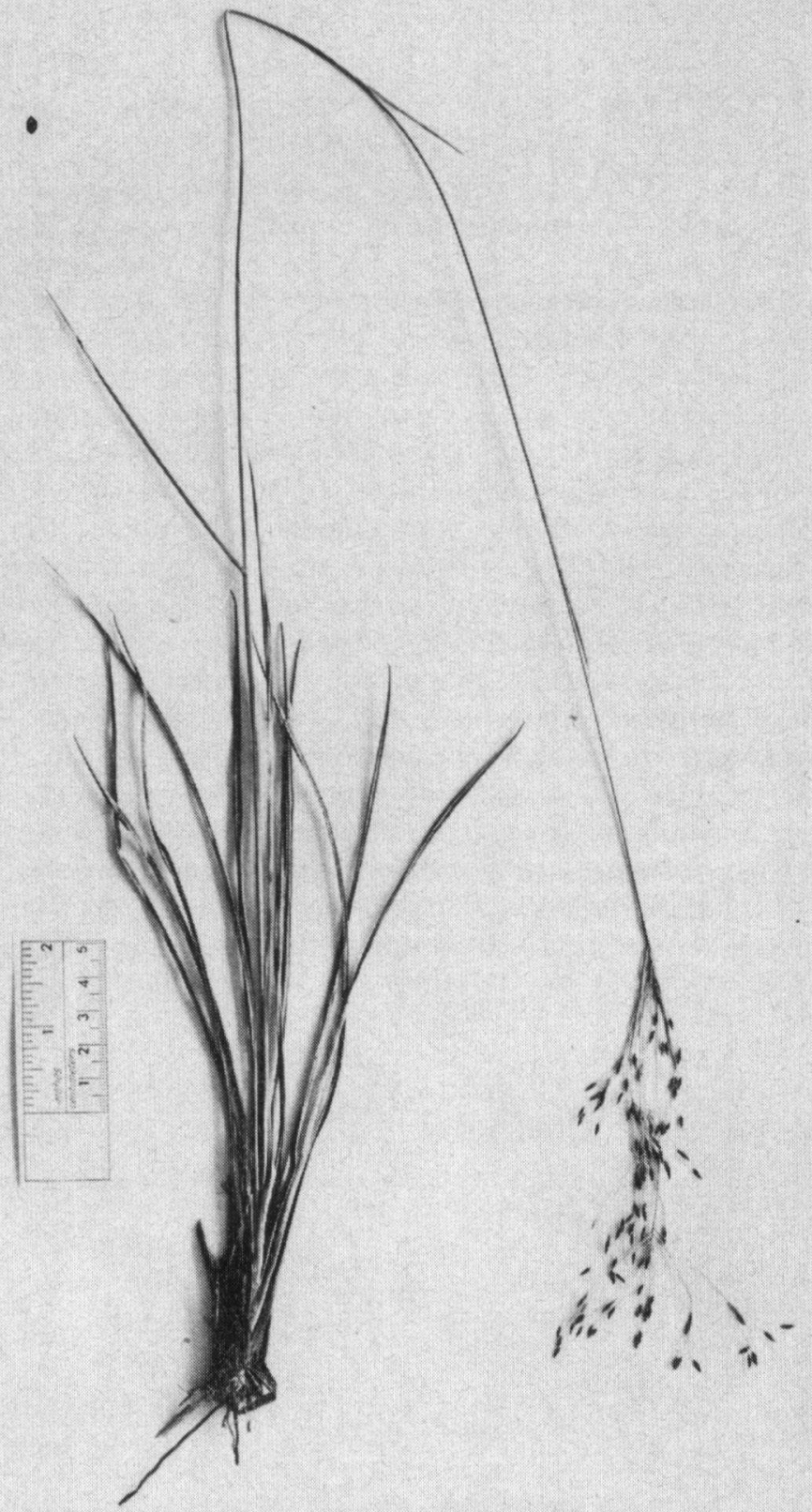

Photo 2. Rhynchospora sublanata (type specimen: Oldenburger \& Norde 952). Photo by A. Kuiper. 
On account of the form of the style-base this species falls into the section $E u$ Psilocarya, which now should be called section Psilocarya as it contains Rhynchospora scirpoides (Torr.) Griseb., the type species of Torrey's genus Psilocarya, indicated by its author. It is most closely related to $R h$. velutina (Kunth) Boeck., widespread in tropical America but not known from Suriname. The main differences with the last-named species are the woolly hairiness of the leaves, the spikelets solitary and narrower, and the shorter base of the style. On the other hand the overall similarity to $R h$. hirsuta Vahl in Kükenthal's section Tenues is striking, but that species differs in the pilose branches of the inflorescence with most spikelets shortly pedicellate, and the much smaller nut tapering into a stipe with a triangular style-base; the surface of the nut, however, is also reticulatetuberculate.

The two specimens from the South (near the airstrips "Sipaliwini" and "Kayser", respectively) were collected on wet sand savannas, probably in vegetation types belonging to the alliance Bulbostylidion lanatae. On the Sabanpasi Savanna in the North the species is restricted to wet localities with a hogwallow structure in a vegetation type belonging to the alliance Axon opodion chrysitidis (TeUNISSEN \& WILDSCHUT 1970, reported by number as an undescribed species).

Not known from outside Suriname.

33a. Rh. tenella (Nees) Boeck. var. tenella

In Fl. Sur. 1,1: 108. 1934.

In the South: on granite flats on the Sipaliwini Savanna, in small quantity of soil (Oldenburger \& Norde 254, 984). Tafelberg: savanna, shallow sand in open places, frequent (Maguire 24251).

Rio Negro (Brazil), Suriname.

33b. Rh. tenella (Nees) Boeck. var. haplostylis (Uitt.) Kük. in Bot. Jahrb. 75: 277. 1951.

In Fl. Sur. 1,1 : 108. 1934, as Rh. tenella Boeck. f. haplostylis Uitt.

One collection in the interior: slope of Mount Teboe $(410 \mathrm{~m})$, on granite rock (Versteeg 776 A).

French Guiana, Suriname.

34. Rh. tenerrima Nees ex Sprengel, Syst. 4 Curae Post. : 26 . 1827.

In Fl. Sur. 1,1: 105. 1934, as Rh. setacea Boeck., non Vahl.

In the North: moist grasslands and roadsides, common. In the South: on wet sand savanna near Zuid River (LBB-Schulz 10437); Sipaliwini Savanna, on wet soil (Oldenburger \& Norde 253, 648), and on rocks in rivulet (idem 850 ).

Tropical South America, Central America, West Indies.

35. Rh. tenuis Link

In Fl. Sur. 1,1: 104. 1934.

In the North: savannas on pure, white sand, moist to very wet; characteristic 
TAXONOMY, ECOLOGY, AND DISTRIBUTION OF RHYNCHOSPORA (CYP.) IN SURINAME

species of the alliance Syngonantho-Xyridion (VAN DonSELAAR 1965; VAN DonselaAR-TEN BoKKel Huinink 1966; Heyligers 1963). On rock in Blanche Marie Rapids, Nickerie River (LBB-Maas 10930). Tafelberg: savanna, wet sands (Maguire 2125la).

Tropical and subtropical America, incl. Mount Roraima and the Kaieteur Plateau (Guyana).

36. Rh. trichodes C.B. Clarke in Urban, Symb. Antill. 2: 116. 1900.

In Fl. Sur. 1,1 : 104. 1934, as Rh. hispidula Boeck.

Only three collections in the North: savanna on heavy soil near Vierkinderen (Lanjouw \& Lindeman 208); along ditch near Livorno (LP-Dirven 285); settlement Jodensavanne (Focke 1319). One collection s.l. (Hostmann 1127).

Northern Brazil, French Guiana, Suriname, Porto Rico.

\section{Rh. triflora Vahl}

In Fl. Sur. 1,2:311. 1968.

In the North: inconspicuous sedge, characteristic of the Lagenocarpus guianensis-other Cyperaceae vegetation in deep swamps in the old coastal plain on floating peat, most frequent in the initial phase (LINDEMAN 1953).

Tropical America, still rarer in tropical Africa and Asia.

38. Rh. viridi-lutea C.B. Clarke in Kew Bull. Add. Ser. 8: 36 et 118. 1908.

In Fl. Sur. 1,1:99.1934, in key only.

In the North: Houttuinweg (Para District), rice field on heavy soil (LP-Dirven $625,626,627)$; in the South: Sipaliwini Savanna, bordering small pool with stagnant water (Van Donselaar 3718).

Northern Brazil, the Guianas.

\section{SOME CONSIDERATIONS ON DISTRIBUTION AND ABUNDANCE OF} THE TAXA

Among the 38 species of Rhynchospora in Suriname 6 species and a variety of a seventh are restricted to the Guianas, viz. $R h$. cephalotes var. angustifolia, fallax, montana, sublanata, arenicola, guianensis, and tenella (both varieties). The four first-named have not even been found so far outside Suriname.

For the present purpose the other species can be divided into three groups (distribution outside America left out of consideration):

a. 10 species with areas the centre of which lies to the South of Suriname: $R h$. albescens, candida, caracasana, comata, denticulata, graminea, heterocaulis, junciformis, reptans, and viridi-lutea. Except for Rh. denticulata, graminea, and reptans these species are rare in Suriname.

b. One species and the variety of 2 others with areas the centre of which lies to the North-West of Suriname, the Suriname station forming a south-eastern outpost: $R h$. fascicularis var. distans, filifolia, and radicans var. watsonii. The first is rare in a limited area in the North of the country, the two others are both 
known from one collection only.

c. 17 species and one variety of 2 others having areas extending from Suriname in all directions: $R h$. armerioides, barbata, brevirostris, the typical var. of cephalotes, corymbosa, curvula, cyperoides, gigantea, globosa, hirsuta, nervosa var. ciliata, podosperma, pubera, rufa, rugosa, tenerrima, tenuis, trichodes, and triflora. Three of these are rare in Suriname, viz. Rh. rufa, trichodes, and triflora. $R h$. armerioides, brevirostris, and hirsuta were found so far only in the South, but there they are not uncommon. The other 13 taxa are common throughout the country in their particular habitats.

Our findings with regard to the variation in abundance of species in different parts of their area are in agreement with a generally known rule: a species becomes increasingly rare in the direction of the extreme limits of its area.

Without trying to interpret the phenomenon in detail we think it worth-while to check in how far the rarity of the species corresponds with rarity of its particular habitat. This appears to be so in the case of $R h$. caracasana, filifolia, and triflora; the special habitat of $R h$. junciformis is not present in the North in sofar as known by the authors.

The species found on the remnants of the Roraima sandstone plateau and the Kappel Savanna are $R h$. arenicola, barbata (f. glabra), cephalotes var. angustifolia, curvula, the typical variety of tenella, and tenuis.

The present distribution of $R h$. arenicola suggests that it had its origin on the plateau. Beside on four of the sandstone table mountains of the Guayana highlands it was found so far only in a limited area in the North of Suriname on sand savannas ecologically more or less resembling those of the table mountains.

The same may be supposed for $R h$. tenella the few collections of which are from Tafelberg, granitic outcrops, and from a habitat near the Rio Negro with a mineral soil, and for $R h$. cephalotes var. angustifolia which is restricted to sandstone or other rock.

For the other species occurring on the Roraima sandstone no statement can be made on the basis of our present knowledge.

\section{ACKNOWLEDGEMENT}

The authors are indebted to Dr. K. U. Kramer for his critical remarks and correction of the English text and the Latin diagnoses.

\section{REFERENCES}

DONSELAAR, J. van (1965): An ecological and phytogeographic study of northern Surinam savannas. Wentia 14: 1-163. Also: The Veg. of Sur. 4; Meded. Bot. Mus. Herb. Rijksuniv. Utrecht 211.

- (1968): Phytogeographic notes on the savanna flora of southern Surinam (South America). Acta Bot. Neerl. 17: 393-404. Also: The Veg. of Sur. 6,1; Meded. Bot. Mus. Herb. Rijksuniv. Utrecht 306.

- (1969): Observations on savanna vegetation-types in the Guianas. Vegetatio 17: 271-312. Also: The Veg. of Sur. 6,3; Meded. Bot. Mus. Herb. Rijksuniv. Utrecht 326.

- \& J. P. Scrulz (in prep.): On the flora and the vegetation of granitic outcrops in the Voltzberg region, with notes on some similar areas in the interior of Surinam. 
TAXONOMY, ECOLOGY, AND DISTRIBUTION OF RHYNCHOSPORA (CYP.) IN SURINAME

DonselaAr-Ten Bokkel Huinink, W. A. E. van (1966): Structure, root systems and periodicity of savanna plants and vegetations in northern Surinam. Wentia 17: 1-162. Also: The Veg. of Sur. 5; Meded. Bot. Mus. Herb. Rijksuniv. Utrecht 256.

HeYLIGERS, P. C. (1963): Vegetation and soil of a white-sand savanna in Suriname. Verhand. Kon. Ned. Akad. Wetensch. afd. Natuurk. ser. 2, 54,3: 1-148. Also: The Veg. of Sur. 3; Meded. Bot. Mus. Herb. Rijksuniv. Utrecht 191.

Kramer, K. U. \& J. van DonselaAr (1968): A sketch of the vegetation and flora of the Kappel savanna near Tafelberg, Suriname, 1 and 2. Proc. Kon. Ned. Akad. Wetensch. C, 71 : 495524. Also: The Veg. of Sur. 6,2; Meded. Bot. Mus. Herb. Rijksuniv. Utrecht 309.

KüKENTHAL, G. (1949-1951): Vorarbeiten zu einer Monographie der Rhynchosporideae, 1618. Bot. Jb. 74: 375-509, 75: 90-195, 273-314.

LiNDEMAN, J. C. (1953): The vegetation of the coastal region of Suriname (135 pp.). Utrecht, Kemink. Also: The Veg. of Sur. 1,1; Meded. Bot. Mus. Herb. Rijksuniv. Utrecht 113.

- \& A. R. A. Görts-van Rijn (1968): Cyperaceae. In Pulle \& Lanjouw (ed.): Flora of Suriname 1,2, additions and coriections: $310-314$. Leiden, E. J. Brill.

Svenson H. K. (1948): Cyperaceae. In Maguire et al.: Plant explorations in Guiana in 1944, chiefly to the Tafelberg and the Kaieteur Plateau - I. Bull. Torr. Bot. Club 75: 91-102.

Teunissen, P. A. \& J. T.Wildschut (1970): Vegetation and flora of the savannas in the Brinckheuvel Nature Reserve, northern Suriname. Verhand. Kon. Ned. Akad. Wetensch. afd. Natuurk. ser. 2, 59,2: 1-60. Also: The Veg. of Sur. 6,4; Meded. Bot. Mus. Herb. Rijksuniv. Utrecht 341.

Uittien, H. (1934): Cyperaceae. In Pulle (ed.): Flora of Suriname 1,1: 72-149. Amsterdam, Vereeniging Koloniaal Instituut. Since 1964: Leiden, E. J. Brill.

- (1943): Cyperaceae. In Pulle (ed.): Flora of Suriname 1,1 additions and corrections: 492505. Amsterdam, Vereeniging Koloniaal Instituut. Since 1964: Leiden, E. J. Brill.

\section{INDEX TO THE NAMES OF SPECIES AND INFRASPECIFIC TAXA}

Synonyms in italics.

Dichromena caracasana Kunth

page

- ciliata Vahl

438

- junciformis Kunth

- monostachya Clarke

- montana Uitt.

- pubera Vahl

- repens Vahl

- watsonii Britton

Isolepis albescens Miq.

Rhynchospora albescens (Miq.) Kük.

- amazonica Poepp. et Kunth var. guianensis Kük.

- arenicola Uitt.

- armerioides Presl

- barbata (Vahl) Kunth f. barbata

- barbata (Vahl) Kunth f. glabra (Maury) Kük.

- barbata (Vahl) Kunth var. glabra Maury

- brevirostris Griseb.

- candida Boeck.

- caracasana (Kunth) Boeck.

- cephalotes (L.) Vahl var. angustifolia Uitt.

- cephalotes (L.) Vahl var. cephalotes

- comata (Link) Schult.

- corymbosa (L.) Britton

- curvula Griseb.

- cyperoides (Sw.) Mart.

- denticulata Huber 


\section{Rhynchospra distans Vahl}

- fallax Uitt.

- fascicularis (Michx.) Vahl var. distans (Michx.) Chapm. 442

- filifolia Gray

- gigantea Link

- glauca Vahl

- globosa (H.B.K.) R. et S.

- graminea Uitt.

- guianensis Lindeman et Van Donselaar

- heterocaulis C. B. Clarke

- hirsuta Vahl

- hispidula Boeck.

- junciformis (Kunth) Boeck. var. junciformis

- longibracteata Boeck.

- montana (Uitt.) H. Pfeiffer

- nervosa (Vahl) Boeck. var. ciliata (Vahl) Kük.

- podosperma C. Wright $\quad 446$

- pubera (Vahl) Boeck. $\quad 446$

- radicans (Schl. et Cham.) H. Pfeiffer var. watsonii (Britton) Kük - 446

- reptans (L. C. Rich.) Kük. 446

- rhizomatosa Lindeman ined. $\quad 440$

- rufa (Nees) Boeck. $\quad 446$

$\begin{array}{lr}\text { - rugosa (Vahl) Gale } & 447\end{array}$

- schmidtii Kük. $\quad 445$

- scirpoides (Torr.) Griseb. $\quad 449$

- setacea Boeck. $\quad$. 449

- sublanata Lindeman et Van Donselaar 447

- subplumosa C. B. Clarke $\quad 434$

- tenella (Nees) Boeck. f. haplostylis Uitt.

- tenella (Nees) Boeck. var. haplostylis (Uitt.) Kük. 449

- tenella (Nees) Boeck. var. tenella 4449

- tenerrima Nees ex Sprengel $\quad \cdot 449$

- tenuis Link $\quad$ - 449

- trichochaeta C. B. Clarke $\quad 440$

- trichodes C. B. Clarke $\quad 450$

$\begin{array}{lr}\text { - triflora Vahl } & 450\end{array}$

- velutina (Kunth) Boeck. $\quad 449$

- viridi-lutea C. B. Clarke $\quad 450$

$\begin{array}{ll}\text { Schoenus distans Michx. } & 442\end{array}$

- rugosus Vahl $\quad 447$

$\begin{array}{ll}\text { Scirpus reptans L. C. Rich. } & 446\end{array}$

This paper will be issued also as:

Mededelingen van het Botanisch Museum en Herbarium van de Rijksuniversiteit te Utrecht no. 354. 